\title{
Surgical treatment of inflammatory perio- dontal diseases using chitosan matrices
}

\author{
Sergey B. Ulitovskiy ${ }^{1^{*}}$, Anna V. Antipova ${ }^{1^{*}}$, Alexander D. Vilesov ${ }^{1^{* *}, 2}$, Galina Yu. Yukina ${ }^{1^{* * *}}$, Dmitry N. Suslov ${ }^{1^{* * *}, 3}$, \\ Pavel V. Popryadukhin ${ }^{1^{* * *}, 2}$, Oleg V. Galibin ${ }^{1^{* *}}$ \\ ${ }^{1 *}$ Department of Preventive Stomatology \\ ${ }^{1 * *}$ Biotechnology Department, R.Gorbacheva Memorial Research Institute of Children Oncology, Hematology \\ and Transplantation \\ ${ }^{1 * *}$ Laboratory of Pathomorphology, The University Research Center \\ ${ }^{1 * * *}$ Laboratory of Invasive Technologies, The University Research Center \\ ${ }^{1}$ First Petersburg State I. Pavlov Medical University \\ ${ }^{2}$ Institute of Macromolecular Compounds, Russian Academy of Sciences \\ ${ }^{3}$ Russian Research A.Granov Center of Radiology and Surgical Technologies, St. Petersburg, Russia
}
Dr. Anna V. Antipova, Assistant Professor, Department
Phone: +7 (921) 9293905
of Preventive Stomatology, St. Petersburg State I. Pavlov
E-mail: ann367@yandex.ru

Medical University

Citation: Ulitovskiy SB, Antipova AV, Vilesov AD et al. Surgical treatment of inflammatory periodontal diseases using chitosan matrices. Cell Ther Transplant 2018; 7(4): 66-71

\section{Summary}

A variety of medications is applied nowadays for treatment of inflammatory periodontal diseases (IPD) which are the prevalent dental disorders worldwide. A method of surgical treatment is described for IPD. We present a classification of natural and synthetic membranes used in surgical interventions, and describe a novel treatment technology using a natural chitosan polymer.

\section{Materials and methods}

Porous 3-D matrices were obtained by lyophilization of chitosan solution from the $2 \%$ solution of acetic acid. The resulting chitosan matrices had micropores of 100 to $150 \mathrm{~nm}$ in size. The in vivo experiments with porous chitosan membranes were performed in rabbits. Artificial maxillar bone defects were inflicted, being overlaid by the tested material. Some animals were subjected to rib exposure and infliction of a bone defect, then filled with a biodegradable porous chitosan-based matrix.

\section{Results}

Morphological examination of artificially damaged ribs with implanted material has revealed various changes of bone tissue and porous matrix, without sufficient inflammation signs. At 1 month, the matrix/bone border has shown osteoclasts at the site of bone defect 30 days after surgery, along with neoangiogenesis at the site of repair. At 3 to 6 months post-surgery, periosteal structures were organized, as well as local fibrosis was developed.

\section{Conclusion}

Porous chitosan matrix proved to be biocompatible, bioinert, and bioresorbable material, thus meeting the requirements applicable to the materials suitable for production of the bone matrices.

\section{Keywords}

Periodontium, regeneration, membrane, chitosan. 


\section{Introduction}

Treatment of inflammatory periodontal diseases (IPD) still represents a lot of issues. The global IPD prevalence among adults, according to the WHO data, is up to $90-95 \%$ without any trends for decrease $[1,2]$. Medical treatment of IPD patients should be performed in combined, purposeful and personalized manner. Both local and general treatment should be applied, using efficient methods of conservative, surgical and prosthetic treatment $[1,2]$.

Moreover, some novel treatments are recently introduced, based on cellular engineering, aiming for partial or total replacement of the damaged tissues. Such techniques presume modeling and construction of biocompatible (scaffold-type) carrier containing medical drugs. The main requirements for the modern matrix materials are as follows: complete biological compatibility, sustained viability of the cells seeded in the matrix, ability for biodegradation and replacement by normal tissues, changes in structure and properties fitting the environmental effects [3].

The tissue engineering techniques are widely used in the IPD surgical treatment, especially when using the so-called directed tissue regeneration (DTR), i.e., a surgical approach which mechanically prevents epithelial migration to the apical side, thus promoting periodontal recovery without usage of natural and synthetic materials for the bone plastics. The method is aimed for creation of physical barrier between the graft and treated dental root surface resulting into preferential migration of slowly regenerating periodontal and bone cells to the affected site [4].

Both biodegradable and non- biodegradable membranes are now used at the present time when performing the directed tissue regeneration (DTR). They may be classified by their origin and composition, as shown in Table 1.

Polytetrafluorethylene (PTFE) is often used for manufacturing the non-biodegradable synthetic membranes. The PFTE non-biodegradable membranes are considered a "golden standard" for the DTR methodology. The results obtained with other membranes are usually compared to this PFTE material which has several advantages: essential mechanical resistance, no bone filler is required, and sufficient barrier properties are present. PFTE drawbacks include a need for repeated surgical intervention 4 to 6 weeks for its extraction, complete closure of the membrane when sealing the flap with reliable fixation; a need for regular weekly or biweekly inspections $[4,5,6]$.
Natural membranes represent structures consisting of animal collagen (xenogeneic), or allogeneic membranes which contain allogeneic collagen supplied by lyophilized demineralized bone, or membranes consisting of xenogeneic collagen and reduced amounts of mineral matrix obtained after partial electrolytic plate demineralization. All these membranes are based on, mainly, type I collagen. Their biodegradation continues for 5 to 6 months, barrier functions retain for 4 months, with good adhesion properties and only rare complications upon their exposure. Such membrane plate is elastic, thus requiring bone plastic materials in order to retain the space. Given long resorption rates, this material should be chosen for defects with presumed slow regeneration. Synthetic membranes are produced as polymeric and gel-like structures. The gel membranes are subject to biodegradation within 9 to 12 months, with their barrier properties kept for 6 months. However, it is more difficult to work with these materials which are rather hard upon polymerization. This type of membranes is now less common applied in dentistry due to problems when handling them. The procedure needs much time in cases of indirect usage, when the membrane is shaped beyond surgical area, followed by introduction to the damaged area $[4,5,6]$.

There are no clear benefits revealed for either biodegradable, or non-biodegradable membranes. Therefore, some authors, when comparing parameters of different materials for the membrane fabrication, have considered chitosan to be the most promising substance which exhibits chondro- and osteoconductive properties, high degree of biocompatibility and complete biodegradation of the polymer, as well as expressed antibacterial activity and homeostatic efficiency [ 7 , $8,9]$.

Chitosan is a desialylated form of chitin polymer which is widely spread in living nature. It seems to be a promising raw material for matrices and biomimetics of bone and cartilageous tissues. At the present time, chitosan is increasingly used in dentistry since it meets the requirements for potential matrix base $[8,9,10]$.

Chitosan applied as the matrix scaffold allows prevention of immune-related synthesis, thus increasing biocompatibility of the composite matrices. Chemical properties of chitosan provide different modifications of its polymer structure, incorporation of various biologically active compounds (both organic and inorganic substances), thus being an important factor. [11, 12, 13, 14]. One should also note that electrostatic and hydrophobic interaction of chitosan with some modifying agents may even enhance its biological activity.

Table 1. Listing of the main membrane types [5]

\begin{tabular}{|l|l|l|}
\hline \multicolumn{2}{|c|}{ Membrane types } \\
\hline Non-biodegradable & Biodegradable & Synthetic: \\
\hline Synthetic & Natural: & a) polymeric; \\
Metal & a) allogeneic laminated demineralized bone; & b) gel-based. \\
& b) xenogeneic collagen; & \\
\hline c) xenogeneic combined. &
\end{tabular}


The aim of this study was to investigate the effectiveness of using chitosan membranes for the treatment of inflammatory periodontal diseases.

\section{Materials and methods}

At the present time, we perform a joint study by the Department of Preventive Stomatology, Department of Biotechnology at the R. Gorbacheva Memorial Research Institute of Children Oncology, Hematology and Transplantology ( $1^{\text {st }}$ St. Petersburg State I. Pavlov Medical University), and the Research Institute of Macromolecular Compounds (Russian Academy of Sciences), concerning development and implementation of an original approach to surgical treatment of inflammatory periodontal diseases using a novel chitosan-based matrix (Fig. 1), as described elsewhere [6].

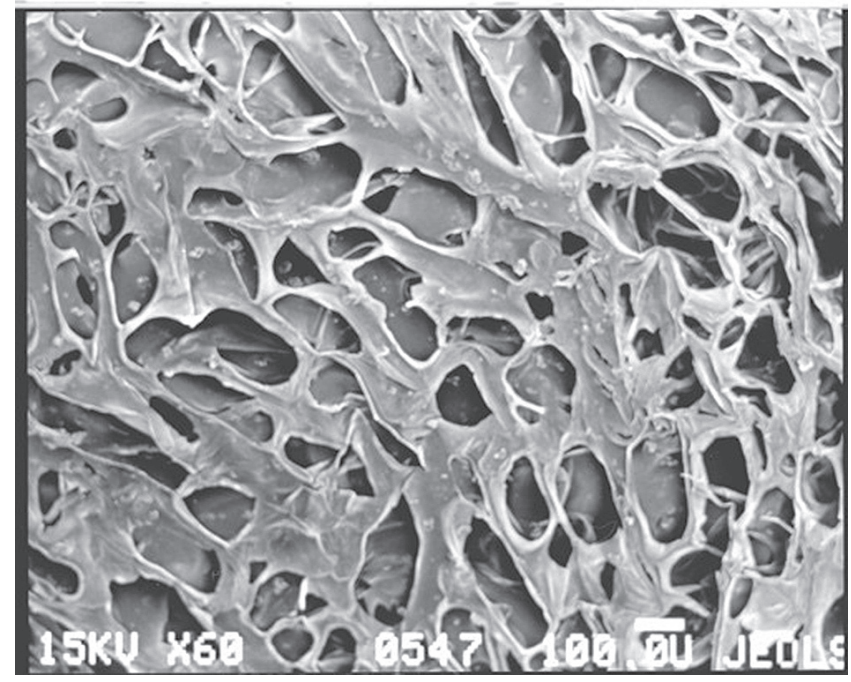

A

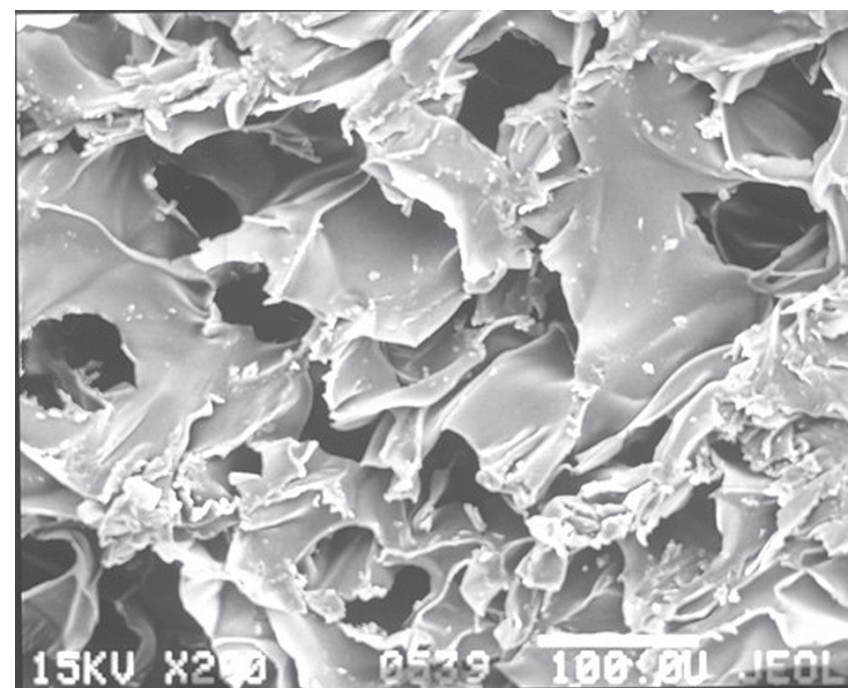

B

Figure 1. A micrograph of chitosan-based matrix was obtained employing Carl Zeiss Supra 55 VP microscopy, magnification 500X. Micrographs (HC. 500X) of chitosan A and B-based membranes were obtained with a Carl Zeiss Supra 55 VP scanning electron microscope

Micrographs A and B are made by P. Popryadukhin
To produce porous membranes, we purchased Chitosan from Fluka Chemie, BioChemika line (molecular mass, 255 $\mathrm{kD}$, deacetylation degree, $80 \%$; ash content, $0.5 \%$ ). Porous 3-D matrices were obtained by lyophilization of chitosan solution by means of Heto-Holten PowerDry PL9000 -50 device. Before drying, chitosan was dissolved in $2 \%$ aqueous solution of acetic acid, at $4 \mathrm{wt} \%$. The solvent sublimation in the lyophilizer proceeded for 48 hours. As seen in Fig. 1, pores in the chitosan matrices look like channels, with the diameter of 100 to $150 \mathrm{~nm}$ [4].

The in vivo experiments with porous chitosan membranes were carried out in rabbits $(\mathrm{n}=10)$. Experimental studies were scheduled and performed according to the Guidelines from the Order No.1179 of 10.10.1983, and No.267 of 19.06.2003 issued by the Russian Ministry of Healtcare, European Convention for the Protection of Vertebrate Animals used for Experimental and Other Scientific Purposes (Strasbourg, 1986), as well as with World Medical Association Declaration of Helsinki (1996).

Table 2 presents the design of experimental study. All surgical interventions proceeded under identical conditions. The surgical manipulations were performed under general anesthesia, i.e., Zoletill00, $0.1 \mathrm{~mL}$, and Rometerum $(20 \mathrm{mg} / \mathrm{mL})$, $0.0125 \mathrm{~mL}$ intravenously.

Two different surgical procedures were performed in rabbits under sterile conditions, aiming for studies of chitosan matrix biocompatibility with adjacent tissues. The surgery was performed in extraoral mode. The operation field was prepared in the right maxillar area. A $5-\mathrm{cm}$ incision was made in maxillar projection, while dissecting the tissue in sharp or blunt way. After accessing the maxilla, an artificial bone defect was inflicted, then overlaid by the tested material. Blood coagulation was controlled, and the wound was closed with suture materials layer-by-layer and treated by a tincture of iodine.

Eight rabbits were subjected to the skin and soft tissue incision at the anterior lateral chest surface followed by a rib exposure and infliction of a bone defect (10 to $12 \mathrm{~mm}$ long). The resulting cavity was filled with a biodegradable porous chitosan-based matrix.

Systemic antibacterial therapy was performed during early postsurgical period (3 days) using Gentamycin (single injections of $2.0 \mathrm{~mL}$ daily for 3 days). After surgical procedures, the rabbits were placed to individual cages. The animals had free access to water and standard diet, being regularly observed.

The animals were kept out of experiment, according to the schedule (1 to 6 months after the surgical intervention), followed by histological studies of gums and ribs, i.e., the areas of artificial bone defects with introduced synthetic materials.

\section{Results}

Three months after surgery, histological assessment of gingival tissues did not reveal any pathological changes of oral mucosa; the multilayer flat non-squamous epithelium and underlying connective tissue did not show any signs of inflammatory response (Fig. 2). 
Table 2. Experimental study design

\begin{tabular}{|l|l|l|l|l|}
\hline \multirow{2}{*}{ Group of animals } & \multicolumn{4}{|c|}{ Number of animals at different terms } \\
\cline { 2 - 5 } & $1 \mathrm{mo}$ & $3 \mathrm{mo}$ & $4 \mathrm{mo}$ & $6 \mathrm{mo}$ \\
\hline $\begin{array}{l}\text { Experimental group, } \\
\text { number of animals }\end{array}$ & 2 & 4 & 2 & 2 \\
\hline Total number & \multicolumn{4}{|c|}{10} \\
\hline
\end{tabular}

Morphological examination of artificially damaged ribs with implanted material has revealed multi-component changes of bone tissue and porous matrix. Morphological analysis of the matrix/bone border area has shown a lot of osteoclasts at the site of bone defect 30 days after surgery (Fig. 3)

Fibrous connective tissue penetrated by blood vessels is developing between the bone structures and porous template. The matrix is repopulated by fibroblasts and macrophages from local blood vessels and connective tissue, as well as from the developing periosteal layer. The entire porous matrix is occupied by connective tissue cells by 30 days of experiment. The intra-matrix fibroblasts are actively producing intercellular components of connective tissue. Due to biodegradation of the matrix and phagocytic activity of macrophages, the microcavities are formed which become larger than initial pores. Hence, the matrix pores and newly developing cavities become surrounded by connective tissue structures containing big amounts of collagen fibers and cell composition typical to the fibrous connective tissue. Moreover, the implant areas adjacent to newly formed periosteum, are more rich in connective tissue, as compared to the more centrally located matrix sites containing only fibroblasts and macrophages. Any signs of inflammatory reaction are observed in connective tissue around the matrix, in developing periosteum, or matrix itself. The porous template is invaded by the blood vessels, and loose connective tissue also develops around them. Arteries and veins are detectable both in central and peripheral areas of the porous matrix. Perivascular cells are invading the matrix, along with connective tissue and vessels [4].

Morphological study of the bone/matrix at 3 months post-surgery has shown the entirely organized periosteum consisting of loose connective tissue and dense fibrous tissue. Over this period, the coarse-fibred connective tissue further expands and fills the bone defect. As a next step of bone regeneration, the coarse-fibred bone tissue and connective tissue periosteum are formed at the $4^{\text {th }}$ month of experiment. At 6 months, the coarse-fibred bone tissue is replaced by a lamellar bone structure. By this term, the regenerating bone has the entirely formed periost represented by loose fibrous and coarse-fibred connective tissue. The latter is gradually replaced by lamellar bone tissue. However, the repair osteogenesis seems to be incomplete due to predominating coarse-fibred bone tissue. Osteons with narrow Haversian canals are observed in the developing lamellar bone structures.

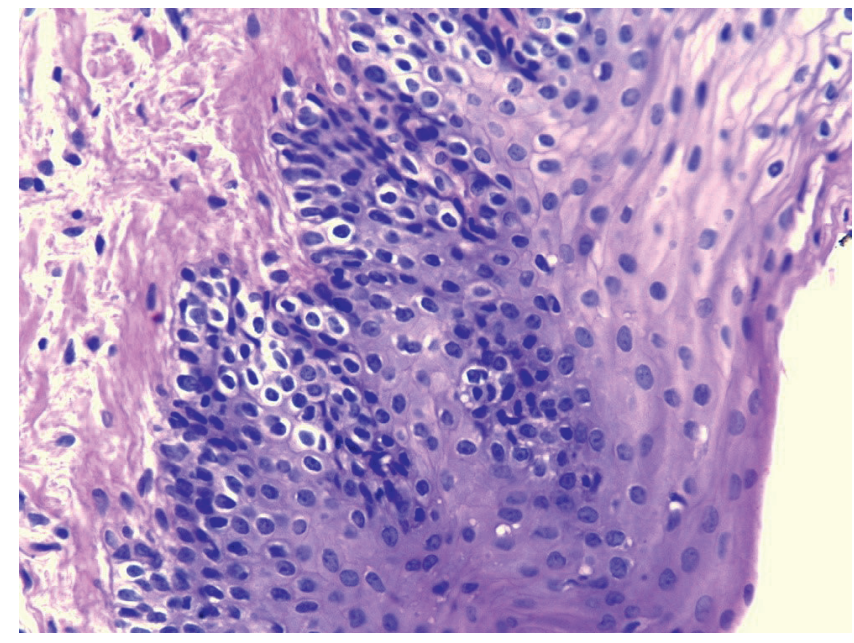

Figure 2. Segment of oral mucosa stained by H\&E, 400X magnification

1, densely stained basal epithelium (in the middle); 2 , intermediate epithelial layer (bottom); 3 , superficial epithelial layer (right); 4 , loose fibrous connective tissue of lamina propria (top left).

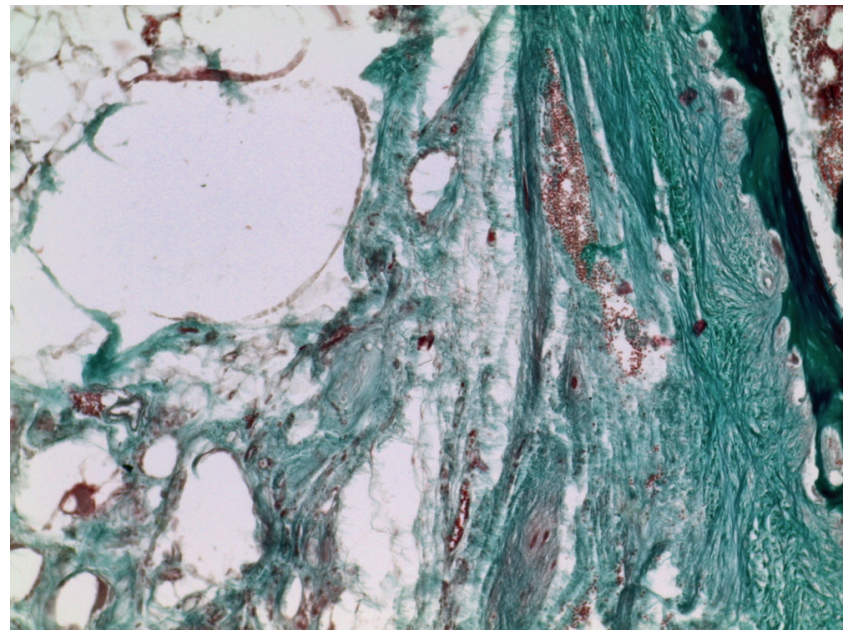

Figure 3. A section of the bone-implant block on day 30 after surgery. Masson stain, 100X magnification

1 , bone tissue (on the right); 2 , newly forming connective tissue (bottom); 3 , porous matrix holes surrounded by connective tissue elements (top left). 


\section{Conclusion}

In the course of experimental study, the porous chitosan matrix proved to be biocompatible, bioinert, and bioresorbable material, thus meeting the requirements applicable to the materials suitable for production of the bone matrices. These properties determine some unique characteristics of chitosan, thus enabling its applications in various areas of medicine, especially in dentistry, when performing surgical treatment for inflammatory periodontal diseases.

\section{Acknowledgements}

We are much appreciated to Vladimir E. Yudin and Irina P. Dobrovolskaya for assisting in preparation of this article.

\section{Conflict of interests}

The authors have no conflicts of interests to declare.

\section{References}

1. Antipova AV, Suslov DN, Yukina GYu, Popryadukhin PV. Use of resorbed membranes for surgical treatment of inflammatory diseases of the periodontium. Dental Scientific and Educational Journal. 2014; 1-2:16-17. (In Russian)

2. Antipova AV, Suslov DN, Yukina GYu, Popryadukhin PV. Development of a new method of surgical treatment of inflammatory periodontal diseases. Dental Scientific and Educational Journal. 2014; 3-4:14. (In Russian)

3. Roach P, Eglin D, Rohde K, Perry CC. Modern biomaterials: a review-bulk properties and implications of surface modifications. J Mater Sci Mater Med. 2007; 18(7); 12631277.

4. Ulitovskiy S.B., Galibin O.V., Thomson V.V., Antipova A.V. et al. The use of surgical techniques in the treatment of inflammatory periodontal diseases. Scientific Notes. 2014;1 (21):71-74. (In Russian).

5. Ulitovskiy S.B., Galibin O.V., Thomson V.V., Antipova A.V. et al. The use of different materials in the process of surgical treatment of periodontal disease. Institute of dentistry. 2014; 2(63):100-101. (In Russian).

6. Ulitovskiy S.B., Galibin O.V., Antipova A.V. et al. Application of new technologies in the treatment of periodontal diseases. Dental scientific and educational journal. 2013;1/2: 2-5. (In Russian).

7. Muzzarelli RA, Mattioli-Belmonte M, Pugnaloni A, Biagini G. Biochemistry, histology and clinical uses of chitins and chitosans in wound healing. EXS. 1999;87:251-264.

8. Di Martino A, Sittinger M, Risbud MV. Chitosan: a versatile biopolymer for orthopaedic tissue-engineering. Biomaterials. 2005; 26(30): 5983-5990.

9. Yang TL Chitin-based materials in tissue engineering: applications in soft tissue and epithelial organ. Int. J. Mol. Sci. 2011; 12(3):1936-1963.
10. Shi C, Zhu Y, Ran X, Wang M, Su Y, ChengT. Therapeutic potential of chitosan and its derivatives in regenerative medicine. J Surg Res. 2006;133(2):185-192.

11. Swetha M, Sahithi K, Moorthi A, Srinivasan N, Ramasamy K, Selvamurugan N. Biocomposites containing natural polymers and hydroxyapatite for bone tissue engineering. Int J Biol Macromol. 2010; 47(1):1-4.

12. Chen JP, Chen SH, Lai GJ. Preparation and characterization of biomimetic silk fibroin/chitosan composite nanofibers by electrospinning for osteoblasts culture. Nanoscale Res Lett. 2012; 7(1):170-178.

13. Biagini G, Pugnaloni A, Damadei A, Bertani A, Belligolli A, Bicchiega V, Muzzarelli R. Morphological study of the capsular organization around tissue expanders coated with N-carboxybutyl chitosan. Biomaterials. 1991; 12(3): 287291.

14. Venkatesan J, Kim SK. Chitosan composites for bone tissue engineering - an overview. Mar Drugs. 2010; 8(8):22522266. 


\title{
Лечение воспалительных заболеваний пародонта с использованием хитозановых матриц
}

\author{
Сергей Б. Улитовский ${ }^{1^{* *}}$, Анна В. Антипова ${ }^{1^{*}}$, Александр Д. Вилесов ${ }^{1^{* *}, 2}$, Галина Ю. Юкина ${ }^{1 * * *}$, \\ Дмитрий Н. Суслов ${ }^{1 * * *, 3}$, Павел В. Попрядухин ${ }^{1^{* * *}, 2}$, Олег В. Галибин ${ }^{1 * *}$ \\ * Кафедра стоматологии профилактической \\ ** Отдел биотехнологии Института детской онкологии, гематологии и трансплантологии им. Р. М. Горбачевой \\ *** Лаборатория патоморфологии НИЦ \\ **** Лаборатория инвазивных технологий НИЦ, ПСПбГМУ \\ ${ }^{1}$ Первый Санкт-Петербургский Государственный Медицинский Университет им. акад. И. П. Павлова МЗ РФ \\ (ПСПбГМУ), Санкт-Петербург, Россия \\ ${ }^{2}$ Институт высокомолекулярных соединений РАН, Санкт-Петербург, Россия \\ ${ }^{3}$ ФГБУ «Российский научный центр радиологии и хирургических технологий им. акад. А.М. Гранова» МЗ РФ, \\ Санкт-Петербург, Россия
}

\section{Резюме}

На сегодняшний день существует большое количество методов лечения воспалительных заболеваний пародонта, являющихся самыми распространенными стоматологическими заболеваниями в мире. Описывается метод хирургического лечения воспалительных заболеваний пародонта, приводится классификация природных и синтетических мембран, использующихся при хирургическом методе лечения, приводится новая технология с использованием природного полимера хитозана.

\section{Материалы и методы}

Пористые трехмерные матрицы получали путем лиофилизации хитозана из $2 \%$ раствора уксусной кислоты. Полученные матрицы из хитозана содержали микропоры размером 100-150 нм. Эксперименты in vivo с пористыми хитозановыми мембранами проводили на кроликах. Животным наносили искусственные дефекты максиллярной кости и покрывали их испытуемым материалом. Некоторым животным наносили повреждение ребра, которое потом заполняли биодеградируемой матрицей из пористого хитозана.

\section{Результаты}

Морфологическое исследование искусственно поврежденных ребер с имплантированным материалом выявило разнообразные изменения костной ткани и пористой матрицы без существенных признаков воспаления. Спустя 1 мес., на границе кости и матрицы отмечены остеокластическая реакция наряду с неоангиогенезом в зоне костного дефекта. Через 3-6 мес. после хирургического вмешательства образовались периостальные структуры, а также зоны локального фиброза

\section{Выводы}

Пористые хитозановые матрицы оказались биосовместимым, биоинертным и биорезорбируемым материалом, что соответствует критериям, применимым к материалам для производства костных матриц.

\section{Ключевые слова}

Пародонт, регенерация, мембрана, хитозан. 